Кобржицький Всеволод В'ячеславович доктор філософії в галузі економіки, професор МКА, професор кафедри менеджменту ННІМЕФ. Міжрегіональна Академія управління персоналом, вул. Фрометівська, 2, м. Київ, 03039, тел.: (044) 490-95-05 (дод. 12-56), e-mail: vsevolodkobr@gmail.com, https://orcid.org/0000-0003-0980-8308

\title{
КОМУНІКАЦІЙНИЙ МЕНЕДЖМЕНТ У ПІДГОТОВЦІ ФАХІВЦІВ МІЖНАРОДНОГО ТУРИЗМУ ТА ІНШИХ ГАЛУЗЕЙ СФЕРИ ПОСЛУГ
}

Анотація. Досліджується проблема використання навчальних дисциплін гуманітарного циклу для подальшого розвитку загальних i професійних компетентностей i знань майбутніх менеджерів міжнародного туризму та інших галузей сфери послуг у вищих навчальних закладах України з метою поліпшення їх володіння знаннями та навичками комунікативного менеджменту як ключового чинника успішної роботи сервісних підприємств.

Визначаються відмінності в роботі менеджерів сфери товарного виробництва та сфери послуг в контексті значення володінням методами та прийомами сучасного комунікативного менеджменту та залежність від нього кінцевих результатів діяльності підприємств.

Вказуються вимоги, що висуваються сучасною практикою бізнесу до менеджерів сфери послуг. Наводяться думки та позиції різних дослідників i навчальних закладів щодо пріоритетності здібностей і поведінкових моделей професійних управлінців виробничників.

Показується значення автокомунікацій для обробки інформаційних потоків, вироблення та прийняття управлінських рішень.

Підкреслюється роль самоорганізації та самоосвіти у професійній підготовці майбутніх менеджерів сфери послуг взагалі та міжнародного туризму зокрема.

Розглядається залежність розвитку комунікаційних здібностей від кількісних і якісних показників володіння іноземними мовами, в контексті чого пропонується вивчення 2-3 іноземних мов з високим рівнем знання і 1-2 3 розмовним рівнем знань, вивчення основ релігії і етнографії туристичних ринків, особливо привабливих для вітчизняних туристів.

Для кращого володіння сучасними комунікаційними процесами майбутнім менеджерам міжнародного туризму потрібно добре володіти комп'ютером i знати основні загальні та спеціальні офісні туристичні програми. Доцільно використати американський досвід індивідуалізації підготовки майбутніх туристичних менеджерів 3 наданням студентам часткової можливості 
самостійного планування кількісних і якісних параметрів навчальних планів 3 вибором дисциплін, викладачів, баз практики.

Ключові слова: комунікації, комунікативний менеджмент, менеджер міжнародного туризму, менеджер сфери послуг, туристські потреби, туристичний ринок, іноземні мови, професійна культура.

Kobrzhytskyi Vsevolod Vyacheslavovych Doctor of Philosophy in Economics, Professor of International Personnel Academy, Professor of the Department of Management, NNIMEF. Interregional Academy of Personnel Management, Kyiv, 03039, Frometivs'ka St., 2, tel.: (044) 490-95-05 (add. 12-56), e-mail: vsevolodkobr@gmail.com, https://orcid.org/0000-0003-0980-8308

\title{
COMMUNICATION MANAGEMENT IN TRAINING OF SPECIALISTS OF INTERNATIONAL TOURISM AND OTHER BRANCHES OF SERVICES
}

\begin{abstract}
The problem of using humanities disciplines for further development of general and professional competencies and knowledge of future managers of international tourism and other branches of services in higher educational institutions of Ukraine in order to improve their knowledge and skills of communication management as a key factor in successful service enterprises.

Differences in the work of managers in the field of commodity production and services in the context of the importance of mastering the methods and techniques of modern communication management and the dependence of the final results of enterprises.
\end{abstract}

The requirements put forward by modern business practice to service managers are indicated. The opinions and positions of various researchers and educational institutions on the priority of abilities and behavioral models of professional managers of manufacturers are given.

The importance of autocommunications for information flow processing, development and management decisions is shown.

The role of self-organization and self-education in the professional training of future managers in the field of services in general and international tourism in particular is emphasized.

The dependence of the development of communication skills on quantitative and qualitative indicators of foreign language proficiency is considered, in the context of which it is offered to study 2-3 foreign languages with a high level of knowledge and 1-2 with a colloquial level of knowledge, to study the basics of religion and ethnography of tourist markets, especially attractive for domestic tourists.

To better master modern communication processes, future managers of international tourism need to have a good computer skills and know the basic general and special office travel programs. It is advisable to use the American experience of individualization of training of future tourism managers with the provision of 
students with a partial opportunity to independently plan quantitative and qualitative parameters of curricula with a choice of disciplines, teachers, bases of practice.

Keywords: communications, communicative management, manager of international tourism, manager of services, tourist needs, tourist market, foreign languages, professional culture.

Постановка проблеми. Кінець XX - початок XXI століття демонструють необхідність подальшого посилення комунікативної підготовки майбутніх фахівців в галузі управління. Наш час ставить нові конкретні вимоги до кожного випускника вищого навчального закладу, а досвід розвинених країн світу переконливо свідчить, що зростання комунік4ативного фактора у всіх сферах управління є об'єктивною закономірністю цивілізованої економіки, всього господарського і духовної діяльності держави, суспільства.

Це спостереження особливо актуальне для галузей сфери послуг, де гостріше, ніж у матеріальному виробництві, відчувається роль та значення успішних комунікацій між учасниками виробничо-збутових процесів, а відтак i значення комунікаційного менеджменту для кінцевого успіху бізнесу є помітно більшим.

Можна стверджувати, що до числа найважливіших завдань вищої школи в підготовці туристичних менеджерів належить забезпечення їх глибокими науковими знаннями, професійними вміннями та навичками. Ці завдання можна втілити в життя при бажанні, наявності здібностей у студентів i, безумовно, їх праці, навчання заради досягнення такого результату. Якісна освіта і виховання туристичних менеджерів становлять основу їх успішної самостійної трудової діяльності, від якої залежать кінцеві результати роботи всієї туристичної галузі.

Сучасна людина завжди перебуває в контакті 3 іншими людьми партнерами реальними або уявними, нав'язаними чи обраними. Тому комунікативна компетентність майбутніх менеджерів передбачає розвиток умінь адекватного самоаналізу та правильної оцінки не тільки власного професійного і психологічного потенціалу, а й потенціалу партнера, чіткого розуміння своїх завдань в кожній конкретній виробничій або життєвої ситуації.

Важливими й актуальними $є$ питання всебічної професійної підготовки майбутніх фахівців - менеджерів з туризму, особливо тих, хто буде працювати 3 іноземними партнерами і клієнтами. У цьому випадку цілком очевидна необхідність в активному спілкуванні, що $\epsilon$ однією 3 найважливіших соціальних потреб, яка з розвитком самої особистості майбутнього менеджера буде розширюватися і заглиблюватися за формою і змістом. І важливі не тільки індивідуальні комунікаційні здібності, але й знання комунікаційного менеджменту, бо молодий фахівець з часом стає професійно та управлінськи більш досвідченим і від його роботи залежить уже не тільки ого власний результат, але й результат роботи підрозділу, всієї турфірми.

Аналіз останніх досліджень і публікацій. Проблеми підготовки сучасних туристичних менеджерів до різнобічних активних комунікацій в межах 
підприємства та поза розглядалися у працях вітчизняних і зарубіжних учених: І.Беха, Н.Волкової, Т.Вяткіної, М.Гудіча, О.Ельбрехт, Ю.Лотмана, І.Найдьонова, Н.Терещенко, В.Федорченка. Однак проблема поглиблення індивідуалізації професійної підготовки в літературі майже не висвітлена.

Мета статті - дослідження особливостей комунікативного менеджменту як засобу підготовки туристичного менеджера до подальшого використання цих умінь і навичок в управлінні туристичним підприємством або його підрозділом.

Виклад основного матеріалу. Сучасні вчені педагоги та психологи вважають, що ефективне і якісне спілкування сприяє розвитку і зміцненню продуктивних соціальних i міжособистісних відносин, a неякісне чи ускладнене спілкування викликає значні труднощі у процесі соціалізації особистості. Тому формування комунікативної компетентності $є$ соціальною умовою, що спирається на педагогічну та психологічну теорії та практики. Воно спрямоване на формування і розвиток належних відносин у професійній діяльності, створення максимально сприятливих умов для професійного вдосконалення і підвищення рівня професійної компетентності майбутнього керівника, який повинен знати й використовувати у своїй практичній управлінській діяльності методи, засоби та прийоми сучасного комунікативного менеджменту.

Підготовка майбутніх менеджерів міжнародного туризму повинна відзначатися не тільки практичною творчою та пізнавальною активністю, а й відповідною комунікативною активністю, яка визначається формами i ступенем участі майбутніх менеджерів в спілкуванні з іншими людьми.

Однак, аналіз навчальних програм і навчальних планів різних вузів, де готують таких фахівців, не свідчить про наявність належної уваги до питання посилення їх комунікативної компетентності.

Звертаючи увагу на виключне значення комунікацій i комунікативного менеджменту саме для сфери послуг, слід підкреслити, що тут одним із ключових завдань є така організація інформаційного обміну між виробником і споживачами, що дозволяє не лише максимізувати швидкість комунікативного процесу, але й виключити його можливе викривлення.

Попри наявність ряду загальних вимог до сучасного менеджера, слід зазначити, що робота керівника сфери матеріального виробництва та управлінця сфери послуг мають істотні відмінності. Їх можна визначити як необхідність особливої адаптивності менеджера сфери послуг до швидкозмінних вимог ринку, потреба постійного тісної взаємодії з клієнтами фірми, миттєву реакцію на найменші зміни їх смаку і попиту. Саме тому менеджер сфери послуг, особливо туризму, повинен:

- добре розуміти галузевої і місцевий ринки;

- володіти основами психології;

- вільно володіти державною та хоча б однією іноземною мовою;

- володіти мистецтвом переконання. 
Знання недоліків свого продукту (послуги) чи бажання клієнтів його удосконалити дозволяє сервісному підприємству невідкладно взятися за поліпшення чи модифікування послуги, що «вже завтра» може бути запропонована замість попередньої, котра отримала певні зауваження від учасників ринку - споживачів.

Сучасні підприємства та організації, котрі надають послуги населенню чи іншим підприємствам, не можуть працювати за принципом виробничого менеджменту, що відштовхується від своїх потенційних можливостей щодо виробництва певного товару з подальшим пошуком способів і каналів його реалізації. Вони повинні перш за все звертати увагу на наявний ринковий попит і на існуючі у потенційних покупців потреби та адаптувати до них свої виробничі можливості та ресурси, адже послуга, як продукт, не може бути відділеною від споживача у процесі виробництва. Вони синхронізовані в часі та просторі. Тобто, лише володіючи ринковою інформацією, сервісне підприємство може створити продукт, котрий у нього придбає споживач. Зрозуміло, що тут особливо важливими $є$ комунікації підприємства 3 клієнтами, постачальниками, співвиконавцями, регулюючими органами та іншими учасниками ринку.

Передавати інформацію можна тільки за допомогою знаків, а точніше знакових систем. При цьому розрізняються вербальна i невербальна комунікації, відповідно до чого сучасна наука виділяє вербальний i невербальний рівні комунікативної складової компетентності. У міжособистісному спілкуванні як знакової системи вербальна комунікація використовує людську вимову, природну звукову мову, тобто таку систему фонетичних звуків, яка включає лексичний i синтаксичний принципи. Як вважає М.М. Чернуха, сукупність певних заходів, спрямованих на підвищення ефективності мовного впливу є «переконуючою комунікацію» [1,C.180].

Комунікативний процес між суб'єктами функціонує на основі певної спільної діяльності. Обопільний обмін ідеями щодо такої діяльності передбачає, що раніше досягнуте розуміння може реалізуватися в нових спільних проектах, діях в майбутньому, для чого потрібно спланувати i організувати спільну сумісну діяльність.

Певну соціальну функцію виконує кожна професія, а іï представники мають своє суспільне призначення, свої цілі. У процесі своєї професійної діяльності ці фахівці формують специфічне середовище для спілкування, що проектує своє відображення на загальну психологічну характеристику, структуру i розвиток професіоналів незалежно від їхнього бажання. Розвиваються також специфічні когнітивна та афективна сфери особистості даної професії, між фахівцями виникають певні специфічні зв'язки і стосунки. Їх слід активно розвивати.

Зрозуміло, що майбутнім менеджерам міжнародного туризму безперечно потрібно добре володіти комп'ютером і знати основні загальні офісні (такі як Word або Excel) i спеціальні туристичні програми (наприклад, Самотур або програми для бронювання квитків, як-то Amadeus, Galileo чи НеоСофт-ТУР - 
новий СОФТ в туризмі, що дозволяє забезпечити найтіснішу інтеграцію 3 партнерами).

Також для полегшення комунікацій слід додати хоча б дві-три іноземні мови 3 високим рівнем володіння, а також знання основ культур і звичаїв народів, у гості до яких їздимо ми і наші туристи або чиїх представників ми радо приймаємо у себе.

У процесі навчання в університеті майбутній менеджер міжнародного туризму на основі розуміння і осмислення як загального морально-етичного змісту майбутньої професії, так і спеціального, тобто професійної етики туристичного менеджера, може ефективно сформувати основні вміння i навички запобігання «антиноміі професійних вчинків», конфліктних форм поведінки, аналізувати і вирішувати складні ситуації, які можуть виникати в процесі його професійної діяльності (незалежно від того, чи виникають він між працівниками одного або різних туристичних підприємств, між представниками туроператорів / турагентів і клієнтами). Тобто, спостерігаємо зростання ролі комунікативного менеджменту в організації та необхідність ретельної підготовки студентів до самостійної роботи у сфері послуг.

3 кінця минулого століття державами значна увага приділяється розвитку управлінської етики. Морально-етичні норми, принципи управління формувалися протягом всієї історії людства. Спираючись на досягнення сучасної етики, можна визначити як загальні етичні норми і принципи функціонування адміністративно-управлінського апарату, так i конкретні етичні основи діяльності професійного управлінця.

При дослідженні підготовки майбутніх менеджерів, звернуло на себе увагу те, що в університетах, інститутах і школах бізнесу, безпосередньо в організаціях різних форм власності та підпорядкування у всьому світі цілеспрямовано ведеться пошук моделі ідеального керівника. У зв'язку з цим O.M. Ельбрехт підкреслює [2,С.149], що в Лондонській школі бізнесу вважають, що менеджер повинен відрізнятися інтелектом, умінням його адекватно застосовувати, особливим стилем організаторської діяльності, відповідною поведінкою, високим рівнем кваліфікації, відповідальним ставленням до роботи тощо.

Для майбутніх менеджерів сервісних галузей особливо цінними i важливими слід визнати ввічливість, тактовність, скромність, точність. Бажаними властивостями менеджера для його самовиховання можна назвати самовладання, доброзичливість, товариськість, наполегливість в досягненні мети, оптимізм і почуття гумору. Саме вони значною мірою відповідають за рівень комунікаційних здібностей менеджера, який повинен постійно (і до того ж успішно) спілкуватися як 3 клієнтами, так і 3 партнерами та власними співробітниками. Від рівня таких комунікацій зрештою залежить успіх роботи менеджера та його фірми.

Цікавою видається думка I.M. Найдьонова [3,С.320-321], який стверджує, що сучасний фахівець-менеджер у своїй роботі повинен дотримуватися таких вимог: 
- пам'ятати ім'я та по батькові своїх підлеглих, завжди вітатися з усіма;

- не зривати гнів на інших, особливо, якщо він роздратований або у нього поганий настрій;

- не підвищувати голос під час розмови;

- не нагадувати багаторазово підлеглому про зроблені ним помилки і вміти визнавати свої;

- вміти цінувати жарт і посміятися разом з усіма, але не над слабкостями підлеглих;

- вміти довіряти своїм співробітникам, дорожити їх часом і не відволікати від основних занять безперервними дрібними дорученнями;

- вміти в міру можливості відгукнутися на прохання підлеглих особистого характеру, не намагаючись потім подати свою участь як неоціненну послугу;

- ввічливо звертатися до підлеглих 3 діловими дорученнями;

- вміти бути досить толерантним до окремих недоліків своїх підлеглих і в повсякденній роботі враховувати це.

Формування ринкових відносин у суспільстві значно впливає не тільки га можливість для прояву ініціативи фахівця, але й висуває нові вимоги до його духовної сфери як у цілому, так і щодо його морально-естетичних якостей зокрема. Робота над собою, самовдосконалення й розвиток власних комунікаційних здібностей є особливо важливими передумовами професійного становлення і розвитку менеджера міжнародного туризму чи будь-якої іншої галузі сучасної сфери послуг.

Оскільки самовиховання тісно пов'язане з самоосвітою, що слід розуміти як цілеспрямовану роботу для поновлення, розширення $\mathrm{i}$ поглиблення отриманих раніше загальнонаукових, професійних, морально-естетичних знань i вдосконалення практичних умінь і навичок для досягнення високого рівня професійної майстерності. Самоосвіта $є$ обов'язковою складовою професійної діяльності фахівця. Початковим етапом становлення справжнього професіонала менеджера є усвідомлення ним необхідності вдосконалення своїх знань, умінь і навичок, подальший розвиток здібностей.

У процесі виховання менеджера сфери послуг майбутнього фахівця доцільно налаштовувати не просто на поглиблення своєї компетентності шляхом подальшого отримання освіти, нових знань, які необхідні йому як сучасній цивілізованій людини XXI століття, але і на всебічне поглиблення та осучаснення його професійних знань.

Якщо розглядати в цьому контексті саме майбутнього менеджера міжнародного туризму, то на чільному місці поруч з вивченням особливостей туристичного ринку, тенденцій його розвитку, впливу політичних i економічних процесів на зміну туристського попиту, має бути поглиблене вивчення культури свого народу, а також культур і мов інших народів, котрі $\epsilon$ головним засобом міжособистісних комунікацій. Саме тому, як слушно вважає В.В.Хмель [4,С.95], методологічні аспекти викладання іноземних мов для спеціальних цілей повинні спиратися на принцип комунікативної спрямованості. 
Вивчення проблеми самопізнання майбутнім туристичним менеджером показує його найбільш значущі блоки, котрі обов'язково слід враховувати як при вивченні загального, так і морально-естетичного плану такого пізнання. Зростає роль автокомунікацій. Тут повідомлення, котре передається в системі «Я - Я» отримує вид певної додаткової інформації, що може перетворюватися й переформатовуватися 3 набуттям нового сенсу чи відтінку. Оскільки при цьому вводиться новий додатковий код, початкове повідомлення перекодовується в одиницях діючої структури та здобуває певні ознаки нового повідомлення. Менеджер, як людина і водночас саморегульована система, має отримувати інформацію щодо оточуючого середовища та власного стану. Поєднуючи та комбінуючи іiі, переробляє і зберігає в пам'яті, класифікує, сортує, відбирає та на основі цього приймає рішення. Виконуючи одну 3 найважливіших функцій менеджера - прийняття управлінського рішення. I після цього знову необхідним стає комунікація з виконавцями цього рішення.

Очевидно, що можна виділити кілька особливо важливих здібностей, що $є$ вирішальними для комунікативної компетентності туристичного менеджера, i які слід максимально розвивати у процесі його виховання та фахової підготовки у ВНЗ: академічні, дидактичні, комунікативні, мовні, організаційні, перцептивні, авторитарні, розподіл уваги та управлінська уява. Розвиток і посилення цих здібностей можливий тоді, коли кожному студентові приділяється максимум уваги особисто. Коли він має змогу додатково спілкуватися 3 тими викладачами, які можуть вплинути саме на його інтелектуальний, культурно-естетичний, фаховий розвиток. Для цього потрібна більша індивідуалізація вищої менеджерської освіти.

Відомо [5,6], що в США діюча система туристичної освіти базується на принципі індивідуалізації навчання, що передбачає врахування особливостей кожного студента та надання йому права вибору навчальних предметів i семестру для їх вивчення, кількості кредитів і годин 3 обраних навчальних дисциплін, формування індивідуальних планів підготовки чи напрямів спеціалізації.

Починаючи 3 третього курсу, студенти американських університетів займаються за спеціально складеними планами, що формуються на основі співвідношення обов'язкових та елективних дисциплін, що зумовлено американським способом життя і $є$ особливо цікавою відмінною ознакою системи освіти в США.

Звичайно, можна провести певну аналогію 3 освітою в Україні щодо дотримання співвідношень дисциплін, але у нас поки що не розвинене явище індивідуалізації навчальних планів для окремих студентів.

Висновки. Узагальнюючи обговорені точки зору на явище комунікативної компетентності, можна стверджувати, що вона виступає інтегральним якістю особистості, яка виконує функцію соціальної адаптації та адекватного функціонування особистості в сучасному соціумі, включає в себе установки, стереотипи, позиції спілкування, ролі, цінності тощо. 
Формування у майбутнього менеджера міжнародного туризму саме комунікативної компетентності, яка спирається на добре знання кількох іноземних мов, має відігравати пріоритетну роль не тільки в процесі його професійної підготовки, а й в контексті формування цілісної і всебічно розвиненої особистості. Цьому може максимально сприяти добре зважений процес його морально-естетичного виховання як студента і самовдосконалення молодого фахівця на шляху до пізнання секретів своєї цікавої і важливої для сучасного суспільства спеціальності.

Доцільно збільшити ступінь індивідуалізації вищої менеджерської освіти 3 метою тісніших комунікацій студентів 3 окремими викладачами та представниками профільного бізнесу.

Володіння засадами сучасного комунікаційного менеджменту дозволить майбутньому менеджеру сфери послуг повніше розкрити свій професійний талант і отримати вищі результати виробничої та творчої діяльності.

\section{Jimepamypa:}

1. Чернуха Н.М., Муромець В.Г. Формування комунікативної компетентності майбутніх фахівців в сучасних соціокультурних умовах // Сучасні педагогічні технології і освітні системи XXI століття: Матеріали VIII Міжнародної науково-практичної конференції 1 жовтня 2010 р. Відп. ред. О.М.Барно. Кіровоград : КІРоЛ «Україна», 2010. 360 с.

2. Ельбрехт О. М. Підготовка менеджерів у вищих навчальних закладах Великобританії, Канади, США: порівняльний аналіз: монографія. АПН України, Ін-т вищої освіти. Київ : Основа, 2009. 248 с.

3. Найдьонов I.М. Етика-естетика: дидактичний зміст. Київ : Кондор, 2011. 550 с.

4. Хмель В. Методологічні аспекти викладання іноземної мови для спеціальних цілей на нефілологічних факультетах університетів. Вища школа. 2015. №4-5 (130). С.87-98.

5. Кобржицький В.В. Північноамериканський досвід підготовки менеджерів 3 туризму з урахуванням релігійного чинника (проекція на українські реалії) / Українська держава і церква: філософські, теологічні та практичні аспекти співпраці в інтересах людини: Матеріали наук.-практ. конф., м. Київ, МАУП, 19 трав. 2016 р. Київ : ДП «Вид. дім «Персонал», 2016. 240 с. (стор. 226-231).

6. The Travel Institute of the Pacific. Режим доступу: http:// https://www.internationalstudent.com/school-search/2820/usa/hawaii/travel-institute-of-the-pacific (дата звернення 10.10.2020).

\section{References:}

1. Chernukha N.M., Muromets V.G. Formation of communicative competence of future specialists in modern socio-cultural conditions. // Modern pedagogical technologies and educational systems of the XXI century: Materials of the VIII International scientific-practical conference on October 1, 2010. ed. O.M. Barno. Kirovograd : KIROL Ukraine Publishing House, 2010. $360 \mathrm{p}$.

2. Elbrecht O.M Training of managers in higher education institutions of Great Britain, Canada, USA: comparative analysis: monograph. Academy of Pedagogical Sciences of Ukraine, Institute of Higher Education. Kyiv : Osnova, 2009.- 248 p.

3. Naidenov I.M. Ethics-aesthetics: didactic content. Kyiv : Condor, 2011. - 550 p.

4. Khmel V. Methodological aspects of teaching a foreign language for special purposes at non-philological faculties of universities. High school. 2015. N4-5 (130). P. 87-98.

5. Kobrzhytskyi V.V. North American experience in training tourism managers taking into account the religious factor (projection on Ukrainian realities) / Ukrainian state and church: 
philosophical, theological and practical aspects of cooperation in the interests of man: Materials of scientific practice. conf., Kyiv, IAPM, May 19. 2016 - Kyiv.: DP "Vyd. House "Staff", 2016. 240 p. (pp. 226-231).

6. The Travel Institute of the Pacific. Access mode: http://https:// www.internationalstudent.com/school-search/2820/usa/hawaii/travel-institute-of-the-pacific (date of application 10.10.2020) 